\title{
AZ EGO-KÖZPONTÚ SZOCIÁLIS HÁLÓ ÉS A KÖTŐDÉSI STÍLUS ÖSSZEFÜGGÉSEI
}

\section{BERÁN ESZTER ${ }^{1}$ - UNOKA ZSOLT ${ }^{2}$ - SOLTÉSZ PÉTER ${ }^{1}$ - RÁCZ ANNA² - KARDOS PÉTER ${ }^{3}$ - PLÉH CSABA ${ }^{4}$}

\author{
${ }^{1}$ Pázmány Péter Katolikus Egyetem, Pszichológiai Intézet, Fejlôdés- és Klinikai \\ Gyermeklélektan Tanszék \\ ${ }^{2}$ Semmelweis Egyetem, Pszichiátriai és Pszichoterápiás Klinika \\ ${ }^{3}$ Bloomfield College, NJ, USA \\ ${ }^{4}$ Közép-európai Egyetem és Collegium de Lyon, Lyon
}

E-mail: eszter_beran@yahoo.com

Háttér: Dunbar társas agy hipotézise szerint az emberi intelligencia és beszédképesség az evolúció során elsốsorban azért fejlôdött ki olyan magas szinten, hogy az egyén átlássa és kezelni tudja a mintegy 150 föt magában foglaló csoportokban kialakuló bonyolult kapcsolati rendszereket. Kutatásunkban azt vizsgáltuk, hogy a nagy csoporton belüli, szoros kapcsolatokból álló kisebb csoportok mérete összefüggésben áll-e a személy kötödési stílusával. Ugyanakkor kíváncsiak voltunk arra is, hogy a vonás jellegú kötôdési stílus hogyan függ össze a szociális hálóban található személyek - alterek - iránti kötôdéssel, valamint arra, hogy az ego-nak az egyes altertípusokhoz való kötódésében találhatók-e eltérések.

Módszerek: Vizsgálatunkat egy 200 személyt magában foglaló mintán végeztük, akik online töltötték ki kérdôivünnket. A kapcsolati háló feltérképezéséhez megkértük a résztvevốket, hogy soroljanak fel minden olyan személyt, akivel személyes kapcsolatban voltak az elmúlt hónapban. Ezután az egyes kapcsolatok értékelését kértük különféle dimenziók mentén, például hogy milyen gyakran találkoznak személyesen, érzelmileg menynyire állnak közel egymáshoz, és hogy hogyan értékelik kapcsolatuk kötôdési jellemzöit. Ezenkíüll a személyek saját magukra vonatkozóan is kitöltötték az ECR-R kérdöivet.

Eredmények: Szignifikáns pozitíu kapcsolatot találtunk az ECR-R szorongást mérö alskáláján elért pontszám és a szimpátiacsoport mérete között. Az ECR-R két alskálája szignifikáns kapcsolatban van az összalteren mért ego-alter kötôdési stílusokkal: minél alacsonyabb az ECR-R szorongás és elkerülés alskáláján elért érték, annál magasabb az ego-alter szinten mért, az egyes alterekhez való biztonságos kötôdés, és annál alacsonyabb a bizonytalan kötôdés értéke. Az ego-szinten mért és az ego-alter szinten mért kötődés összefüggései altertípusonként vizsgálva eltérést mutatnak.

Következtetések: A kötôdési kapcsolat biztonságossága összefüggést mutat a kapcsolati háló szerkezetével, és annak méretével is, s mint ilyen fontos jellemzôje lehet a kapcsolati háló szervezôdésében megfigyelhetô egyéni különbségeknek. Az általános, vonás jellegú kötôdési stílus eltérô módon határozza meg a szociális háló egyes kapcsolati típusába tartozó személyekhez való kötôdést. Az egyes altertípusokhoz fúzôdô eltérô kötôdés arra utal, hogy a vizsgált személyek több, eltérô kötôdési modellt használnak különbözó személyes kapcsolataik értékelésekor, ami felnöttek körében megkérdôjelezi a monotropikus modell érvényességét.

Kulcsszavak: kötôdés, kapcsolati háló, támogató csoport, szimpátiacsoport, ECR-R 


\section{A TÁRSAS HÁLÓ ÉS KÖTŐDÉSI STÍLUS ÖSSZEFÜGGÉSEI}

Dunbar társas agy hipotézise (Dunbar, 1993, 1996, 2003a, 2003b; Dunbar és Shultz, 2010) szerint az emberi intelligencia és beszédképesség az evolúció során elsôsorban azért fejlődött ki olyan magas szinten, hogy az egyén átlássa és kezelni tudja a mintegy 150 fốt magában foglaló csoportokban - hordákban - kialakuló bonyolult kapcsolati rendszereket. A hordán belüli kapcsolatok azonban érzelmi intenzitás és energiaráfordítás szempontjából nem mind egyenértékúek. Dunbar az egyént - az én-t vagy ego-t - körülvevô koncentrikus körökkel szemlélteti a kapcsolati háló rétegzettségét (Dunbar és Shultz, 2010; Hill és Dunbar, 2003). A két legbelsố körben, a támogató és a szimpátiacsoportban az energiaráfordítás magasabb: a személyek gyakrabban találkoznak személyesen, és intenzívebb érzelmi kapcsolatban vannak egymással, mint a külsố körök tagjaival. Az ego kapcsolatainak - altereinek - számát azonban Dunbar szerint nemcsak a neocortex mérete befolyásolja, hanem az olyan kapcsolattartáshoz szükséges kognitív és érzelmi képességek is, mint az emlékezeti rendszer, az elmeolvasás és a kötődési képesség.

A kötődési személyek számára vonatkozó kutatások egybehangzóan azt találták, hogy a kötổési személyek száma nem korlátlan. Ez a szám leginkább a támogató és szimpátiacsoport Dunbar által meghatározott mérete körüli. Különféle kultúrákban, mint például Nigériában (Marvin, Van Devender, Iwanaga, LeVine és LeVine, 1977) és Németországban (Grossmann és Grossmann, 1991) a megfigyelt kisgyerekek 3-4 kötốdési személynél többhöz nem kötôdtek. Amerikai, 9-12 év közti gyerekeknél átlagosan 5,3 (1-10 közötti számú) személy került a teljes, a kötôdés kritériumait kielégítố belsố körbe (Seibert és Kerns, 2009). Egy másik vizsgálatban azt találták, hogy amerikai fiatal felnôttek körében is 3 és 6 közötti volt a kötôdési személyek száma (Trinke és Bartholomew, 1997). Feltételezhetjük, hogy a kötôdés kialakításához és fenntartásához szükséges képességek és a ráfordítható idôkorlát befolyásolhatják a háló szerkezeti sajátosságait is.

Kutatásunk célja, hogy megvizsgáljuk a kötôdés és a kapcsolati háló méretének és szerkezetének összefüggéseit a dunbari modell két belsố körében, a támogató és a szimpátiacsoportban. Elôzetes vizsgálatok (Fiori, Consedine és Merz, 2011) alapján feltételeztük, hogy a kötôdési biztonság pozitív kapcsolatban áll a háló méretével, valamint hogy az ECR-R kötôdési szorongást és elkerülést mérô skáláin elért pontszám elôre jelzi az én-nek az egyes altereihez fúződô kötôdési stílusát. Ugyanakkor azt is vizsgáltuk, hogy az hogy az ego-nak az egyes altertípusokhoz (pl. szülō, barát, partner, expartner) való kötôdésében találhatók-e eltérések.

\section{Az ego-központú szociális háló}

A társas agy elmélet Dunbar nevéhez fúzôdik. Az elmélet lényege, hogy az emberi fajnál az evolúció során bekövetkezett fejlódést, mint például az intelligencia növekedését vagy a nyelv kialakulását, a csoportokban kialakuló társas funkciókból vezeti le. Feltételezése szerint a mai társadalomban a csoportszerkezet ez egyes személyek körül elhelyezkedô ego-központú szociális hálóval modellezhetô. Dunbar és munka- 
társai ( Dunbar, 1993; Dunbar és Shultz, 2010; Hill és Dunbar, 2003) szerint ennek az ego-központú hálónak a mai felépítése evolúciós nyomásra alakult ki. Azt figyelték meg ugyanis, hogy a csoportban élô fốemlősöknél a neokortex nagysága pozitív kapcsolatban áll a csoportmérettel. Ennek okát abban látták, hogy ezek az állatok egyénenként megkülönböztetik egymást a csoporton belül. A nagyobb csoportméret evolúciós elônnyel jár: nagyobb védelmet nyújt a ragadozók és külsô csoportok támadásai ellen. Dunbar szerint a csoportméret és a neokortex nagysága közötti összefüggés a korai humanoid csoportokra is jellemzó volt, vagyis az emberré válás során az agyméret nagyságával együtt növekedett a csoportméret is. Ugyanakkor a csoportmérettel együtt növekedett a csoporton belüli kurkászással, vagyis kapcsolattartással töltött idô is (Dunbar, 1993, 2003a,b; Dunbar, Barrett és Lycett, 2005). Másként fogalmazva Dunbar és munkatársai azt állítják, hogy a neokortex mérete a mai embernél behatárolja azt a maximális csoportnagyságot, ahol a kapcsolattartásra még megfeleló idó jut. Dunbar szerint ez a maximális szám a mai embernél megegyezik az ôskori hordák vagy törzsek méretével (Dunbar és Spoors, 1995), azaz mintegy 120-150 fớre tehetô (Pléh, 2016).

A nagyobb csoporton belül Dunbar elmélete szerint több kisebb méretú csoport is található, melyek diszkrét hierarchikus rétegeket alkotva veszik körül az ego-t, amint azt az 1. ábra mutatja.

Az ego körül elhelyezkedô rétegek eltérô funkciót töltenek be a személy és a csoport társas szükségleteinek szempontjából. A belsố rétegek feladata az egyén felé nyújtott érzelmi támogatás és az információ megosztása, míg a külsô rétegek a más csoportok elleni védelmet biztosítják, valamint a közeli barátok és társak keresésére alkalmasak (Hill és Dunbar, 2003). Az érzelmi közelség és intimitás a csoporttagok között fokozza a csoporton belüli kohéziót és a kooperációt. Ugyanakkor a közeli kapcsolatokhoz szükséges intimitás fenntartása idô- és energiaigényes az ego számára. Egyes kutatások

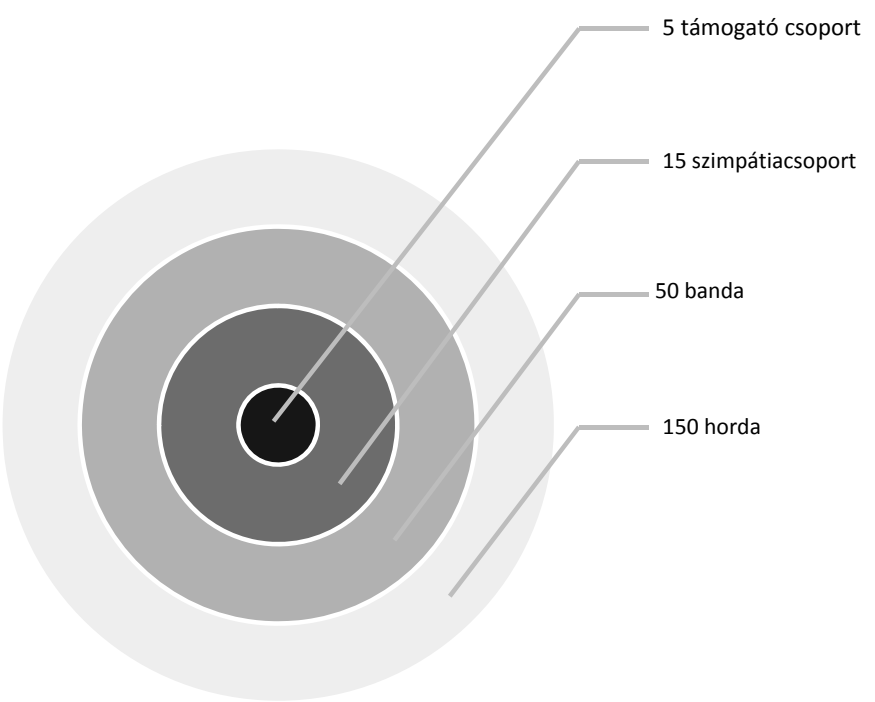

1. ábra. Az ego-központú háló négy koncentrikus köre a magtól a perifériáig (Pléh, 2016, 48 alapján) 
kimutatták, hogy a szubjektíven megítélt érzelmi közelség lineáris kapcsolatban van a személyes kontaktus gyakoriságával (Roberts, Dunbar, Pollet és Kuppens, 2009). Így az egymásra épülô hálózati rétegek közül a belsố rétegeknél - Dunbar elnevezése szerint a támogató és szimpátia csoportban - gyakoribb a személyes kontaktus (pl. naponta), és az intenzívebb érzelmi kapcsolat. A külsô rétegeknél - Dunbar elnevezése szerint a bandában és hordában - ezzel szemben a személyes találkozások ritkábban, például évente fordulnak elô, és az intimitás is kevésbé jellemzô (Hill és Dunbar, 2003). Ugyanakkor a csoportméret és a kapcsolat erôssége inverz viszonyban állnak: a legszorosabb kapcsolatok a támogató csoportban jellemzóek, ezt követi a szimpátiacsoport, míg a bandában és hordában, vagyis a külsô rétegek felé haladva egyre gyengül a kapcsolatok erôssége. Az ego feladata, hogy megtalálja az egyensúlyt a gyenge és erôs kapcsolatok között és kialakítsa az optimális ráfordítás- és nyereségarányt (Sutcliffe, Dunbar, Binder és Arrow, 2012).

A csoporton belüli kapcsolattartás a mai embernél speciális kognitív és érzelmi funkciók használatát követeli meg. Ilyenek például az emlékezeti rendszer, a kötôdési rendszer és az elmeolvasás képessége. A különféle kognitív kapacitások és képességek szintén hozzájárulhatnak a kapcsolati hálók szerkezeti felépítéséhez, és behatárolhatják a támogató és szimpátiacsoportok méretét, amiben egyéni különbségek mutatkozhatnak (Roberts, Dunbar, Pollet és Kuppens, 2009). A korábbi kutatások szerint a kognitív és az érzelmi funkciók közül az egyik legfontosabb a kötôdési képesség (Shultz és Dunbar, 2010; Bickart, Hollenbeck, Barrett és Dickerson, 2012), ami összefüggésben állhat az amigdala nagyságában mutatott egyéni különbségekkel is.

\section{Kötôdési modellek}

Bowlby (1969/1982) elmélete szerint a kötôdés belsô munkamodellje a csecsemôkortól fogva más fontos személyekkel, gondozókkal együtt töltött idô során kialakult kép arról, hogy mit várhatunk a másiktól. Bowlby elsôsorban két alapvetô szempontot jelölt meg a belsô munkamodell alakulásának szempontjából: elérhetô-e a gondozó, amikor szükség van rá, és megfeleló érzékenységgel reagál-e a csecsemő szükségleteire. A belsố munkamodell kialakulása tehát Bowlby szerint a korai kapcsolatok függvénye. Az ebben szerzett tapasztalatok meghatározóak az érzelmi kapcsolatok szempontjából a személy egész életében. Bowlby és Ainsworth kutatásai (Bowlby, 1969; Ainsworth, 1979) négy kötôdési típust írtak le 1 éves gyermekeknél az Idegen Helyzetben tanúsított viselkedésük alapján. Ennek során elkülönítették a biztonságosan kötôdô gyermekeket és a bizonytalanul kötôdô típusokat (elkerülő, ambivalens, és dezorganizált). A biztonságos kötôdésú gyermekek képesek voltak jelentôségteli kapcsolatok létesítésére, empátiára és megfelelô személyközi határok felállítására. A késôbbi fejlôdés során a gyermekkorban kialakult biztonságos kötôdés kapcsolatot mutatott a lelki egészséggel és jólléttel (Collins és Feeney, 2004; Collins és Read, 1990; La Guardia, Ryan, Couchman és Deci, 2000).

Bowlby szerint a kora gyermekkorban kialakult kötődési mintázatok felnôttkorban is meghatározzák a kapcsolódás minôségét intim helyzetekben. A felnôtt kötôdési típusok jellemzőit az intim kapcsolatokban Hazan és Shaver (1987), valamint Bartholomew és 


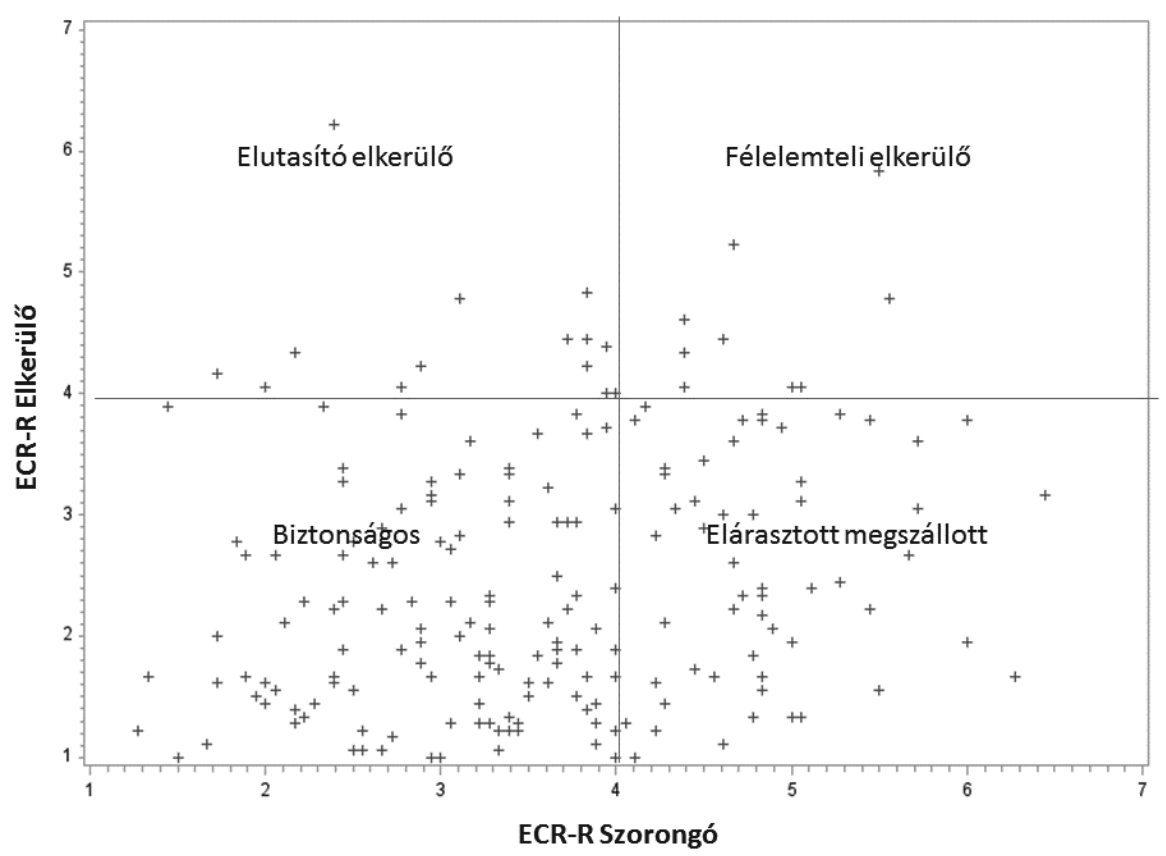

2. ábra. A vizsgálati személyek eloszlása az ECR-R szorongó és elkerülô skáláin elért értékeik által kijelölt, a négy fố kötôdési típus által felosztott kétdimenziós térben

Horowitz (1991) dolgozták ki. Ez utóbbi szerzôpáros kérdőívében a kötôdési szorongás és elkerülés skálái bizonyultak alkalmasnak a kötődés minôségének mérésére. Eszerint a biztonságos kötôdés felnôtt korban alacsony kötôdési szorongással és alacsony elkerüléssel jár. Az ebbe a csoportba tartozó személyek (a populáció 65\%-a) viszonylag egyszerûnek találják a másokkal való intim együttlétet és érzelmi közelséget, valamint a másoktól való kölcsönös függést. A bizonytalanul kötôdô felnôtteket Bartholomew és Horowitz (1991) három alcsoportra osztotta: elárasztott/megszállottra, félelemteli elkerülôre és elutasító elkerülőre. Az elárasztott/megszállott személyek sokat szoronganak attól, hogy elveszíthetik kapcsolataikat és mások nem viszonozzák érzelmeiket. A szorongás skálán magas, míg az elkerülés skálán alacsony értéket érnek el. Az elutasító elkerülô kötôdésú személyek kényelmesen érzik magukat akkor is, ha nincsenek szoros érzelmi kapcsolatban másokkal. Az elkerülési skálán magas, míg a szorongás skálán alacsony pontszámot érnek el. A félelemteli elkerülő személyek vágynak az érzelmi közelségre, de nehezen bíznak meg másokban, és nehezükre esik a másoktól való függés. Pontszámuk a szorongás és az elkerülés skálán is magas. A kötôdés fenti kategoriális modellje mellett dimenzionális modelleket is kidolgoztak. Ilyen például az ECR, ami a kötôdési szorongás és elkerülés dimenzióik segítségével méri a személy kötôdési stílusát a felnôtt partnerkapcsolatokban (ECR; Brennan és mtsai, 1998) és az ECR-R-t (ECR-R; Fraley, Waller és Brennan, 2000). Fraley és Shaver (2000) javaslata szerint a Bartholomew-Horowitz-féle négy kötődési típus definiálható a szorongás és elkerülés tengelyén adott értékek kombinációjával is (2. ábra). 


\section{Az anyaközpontú monotropikus modell vs. a szociális háló kötôdési modellje}

A Bowlby nevével fémjelzett kötôdéselmélet azon a feltevésen alapul, hogy megfelelő anya-gyermek kapcsolat nélkül a többi társas kapcsolat is jelentôsen károsodik (Berán és Unoka, 2016). E nézet szerint a kapcsolati reprezentációk fejlődése egy viszonylag rögzített szekvenciát követ: az egyik társas interakcióból következnek a további kapcsolati interakciók. Ennek oka, hogy a gyermek adaptálódik a kezdeti interperszonális tapasztalathoz, és ez formálja a késóbbi társas kapcsolatait más felnôttekkel és gyermekekkel. Bowlby pszichoanalitikusként a freudi elméletból indult ki a kötôdés koncepciójának megfogalmazásakor. A freudi gondolat egyik fontos eleme az anya-gyermek kapcsolat. Az anya a gyermek elsó szeretet tárgya, egyedi, és nincs hozzá mérhetô; a hozzá való kapcsolódási mód az összes többi kapcsolat prototípusa (Freud, 1982).

Az anya e kiemelt szerepét a kötôdésben sok adat megkérdôjelezte. Az emberi evolúció során a gyermekek családokban nevelkedtek, amelyek nagyobb, különbözó méretû és összetételú csoportok részét alkották. A legtöbb gyermeknek több gondozóval volt kapcsolata, ami lehetôvé tette, hogy több gondozóhoz is kialakítson kötôdési viszonyt. Több kutatás bizonyította, hogy másfél éves kor felett a gyermek egynél több kötôdési személyhez is kapcsolódik, bár ezek a személyek nem egyforma jelentôségúek a gyermek számára (Ainsworth, 1969; Konner, 1976; Marvin, és mtsai, 1977; Schaffer és Emerson, 1964; Myers, Jarvis és Creasey, 1987). Stressz, éhség és betegség esetén a gyermekek egyetlen kötôdési személyt preferálnak akkor is, ha több ilyen személy van jelen. Ugyanakkor más vizsgálatok azt is kimutatták, hogy a kötôdési személyek elsôdlegessége kontextusonként és szükségletekként változhat. Vagyis a kötôdési személyek hálózatában az egyes kapcsolatok más-más funkcióval bírnak (van IJzendoorn és Sagi-Schwartz, 2008). Egyes elméletek szerint az anya-gyermek kapcsolat nem szükséges és elégséges feltétele minden késôbbi kapcsolatnak (Harlow, Harlow, Dodsworth és Arling, 1966; Lewis, 1987). Eszerint az anya-gyermek és a kortárs-gyermek kapcsolatok különálló párhuzamos rendszerek, melyeknek lehetnek közös pontjai. Emellett több olyan kapcsolat van, amelyben a másik személy, például barátok, munkatársak, iskolatársak, alkalmanként az „idôleges kötôdési személy” szerepét tölthetik be, főleg amikor a fố kötôdési személyekhez való hozzáférés átmenetileg gátolva van (Schuengel és van IJzendoorn, 2001).

A szociális háló modell szerint a kapcsolatok különféle rendszerei, amelyek különbözô társas szükségleteket elégítenek ki, egymással párhuzamosan fejlôdnek a (Lewis, 2005). A csecsemôkortól az idôs korig mindenki szimultán alakít ki és tart fenn jelentôs kapcsolatokat a családon belül és azon kívül (Antonucci, Akiyama és Takahashi, 2004). A szoros kapcsolatok, melyek túlélésünket és létünket biztosítják, nem csak aszimmetrikus kapcsolatokból állnak (mint amilyen például a gyermek és gondozója közötti kapcsolat), hanem kölcsönös kapcsolatokból is. A kölcsönös kapcsolatok egyik legfontosabb funkciója az érzelmek és élmények megosztása másokkal. Eszerint az anyához fúzôdô kapcsolat egyesek számára a legfontosabb kapcsolat, míg más személyek esetén ez nem így van. Az anya egy a többi kiemelt személy között, szerepe a többi személy szerepével áll kapcsolatban, és függ azoktól.

A szociális háló modell a kötôdés fejlôdésében megfigyelhetô folyamatosságot és diszkontinuitást egyaránt hangsúlyozza. Egyfelôl a már kialakult kapcsolatok közve- 
1. táblázat.A szociális háló és a monotropikus modell összehasonlítása (Berán és Unoka 2016, 138)

\begin{tabular}{l|l|l}
\hline & Kötôdés modell & Szociális háló modell \\
\hline Fókusz & $\begin{array}{l}\text { diádikus kapcsolatok } \\
\text { anya-gyermek } \\
\text { gyermek-barát } \\
\text { szerelmi partnerkapcsolat } \\
\text { házastársi kapcsolat }\end{array}$ & $\begin{array}{l}\text { egyszerre fennálló több } \\
\text { kapcsolat }\end{array}$ \\
\hline Minta életkora & $\begin{array}{l}\text { csecsemốgyermekkor } \\
\text { felnôttkor }\end{array}$ & kamaszkor-felnôttkor \\
\hline $\begin{array}{l}\text { Fejlôdés szempontjából ki- } \\
\text { emelt kapcsolat }\end{array}$ & gyermek-anya & kamasz-szociális háló tagjai \\
\hline $\begin{array}{l}\text { Kiemelt elsố kapcsolat hatá- } \\
\text { sa a késôbbi kapcsolatokra }\end{array}$ & $\begin{array}{l}\text { gyermek-anya kapcsolat kor- } \\
\text { látozza a későbbi kapcsolatok } \\
\text { alakulását }\end{array}$ & $\begin{array}{l}\text { a kamasz paralel kapcsolatai } \\
\text { egyaránt fontos szerepet játsz- } \\
\text { hatnak, kiegészítik egymást, } \\
\text { koronként más-más hangsúlyt } \\
\text { kapnak a kapcsolatok }\end{array}$ \\
\hline
\end{tabular}

títik és korlátozzák az egyén jelenlegi és késôbb kialakuló kapcsolatainak minôségét. Másfelôl a közeli kapcsolatok minôségét megváltoztatja az újonnan kialakult kapcsolat vagy a kapcsolatok elvesztése (Lewis, 2005). Az alábbi táblázatban összevetjük a szociális háló modellt az anya-központú monotropikus modellel.

A szociális hálót vizsgáló kutatások azt találták, hogy az egyén felnôtt korban több fontos közeli kapcsolattal rendelkezik, melyek szükségesek a túléléshez és jólléthez. Az egyének pszichológiai biztonságuk maximalizálása érdekében több társat választanak ki maguknak, és mindegyikhez más-más pszichológiai funkciót rendelnek, valamint más-más szerepet osztanak ki nekik. Ugyanakkor az egyének saját maguk konstruálják meg a közeli kapcsolatok társ-funkció párok halmazaiból álló belsô körét. Eszerint a különbözô kapcsolatok, például az apa, az anya, a testvérek, a szerelmi partnerek, a barátok, illetve a munkatársak, eltérô társas szükségleteket elégítenek ki és funkciókat töltenek be, mint például a védelem, gondoskodás, táplálás, játék, felfedezés/tanulás, szexualitás, valahova tartozás (Lewis, 2005).

Jelen kutatásunk célja, hogy a fenti szociális háló modellt összevessük a kötôdés minốségi jellemzőit leíró modellel, és megvizsgáljuk, hogy a kötôdés minôségi jellemzôi milyen összefüggésben állnak a szociális háló Dunbar által leírt belsô szervezôdésével. Ennek értelmében vizsgálatunk a dunbari modell két belsô körére, tehát a szoros kapcsolatokra terjed ki, vagyis a támogató és szimpátiacsoportra. Ezzel kapcsolatban Fiori és kollégái (Fiori, Consedine és Merz, 2011) a kötôdési minôség és az ego-központú szociális háló méretének összefüggéseit vizsgálta. Vizsgálatukban kimutatták, hogy azoknak a személyeknek, akik biztonságosan kötôdtek, a szociális hálójuk kiterjedtebb volt, mint a bizonytalanul kötôdôké. Továbbá a biztonságosan kötôdôk kapcsolatait magas reciprocitás jellemezte. Azonban a szociális háló dunbari rétegeiben a szoros kapcsolatok számát, vagyis a támogató és szimpátiacsoport mérete és a személy kötôdési stílusa közötti összefüggést nem vizsgálták.

A kötôdési munkamodellt személyiségvonásként definiálják a felnôtt kötôdési kérdôívek kidolgozói. Ennek megfelelôen a munkamodell mérésére kidolgozott kötôdési 
kérdőívekben arra kérik a vizsgálati személyeket, hogy közeli kapcsolataikat általánosságban értékeljék az egyes kérdések megválaszolásakor. Ez a módszer arra a feltételezésre épül, hogy az egyén belsô munkamodellje viszonylag jelentôs hatást gyakorol a kapcsolatokra a kapcsolati kontextusok széles körében, beleértve a szülőkhöz, testvérekhez, barátokhoz, szerelmi partnerekhez füződô kapcsolatokat (Hazan és Shaver, 1987). Jelen vizsgálatunkban használt kérdôívben például azt kérik a kitöltôktôl, hogy partnerkapcsolataikról általában nyilatkozzanak és ne a jelenlegi partnerkapcsolatukról (Nagy, 2005).

A kötôdés globális, vonás jellegú felfogásának sikerességét kiterjedt irodalom támasztja alá (Ravitz és mtsai, 2010). Azonban kétségek is felmerültek, mivel a kutatási eredmények szerint jelentôs személyen belüli variabilitás figyelhetô meg az egyes kötôdési személyekre vonatkozó belsố munkamodellek tekintetében. A kontextusra specifikus munkamodellek hipotézis szerint például a szüleinkrôl alkotott munkamodellünk jelentôsen eltérhet a testvérünkrôl, partnerünkrôl, gyerekünkrôl, barátunkról, munkatársainkról alkotott munkamodellektôl. Az agyméret és a társas kogníció fejlettsége talán azért is állhat szoros kapcsolatban a hálózat belsô köreinek méretével, mivel ezeket az eltérô és komplex személyfüggő kapcsolati modelleket folyamatosan észben kell tartani és rugalmasan, kontextusspecifikusan alkalmazni. Vizsgálatunk egyik célja a fenti kérdések további tisztázása, és ezért a résztvevôk általános, vonásszintû kötôdése (ego-szint) és kapcsolati hálójuk egyes személyeihez (ego-alter szint) füzôdô kötôdése közötti kapcsolatot vizsgáltuk. A kötôdés vonás jellegú, és a monotropikus modellben elképzelt hipotézise szerint a vonás jellegú kötôdés és kontextusspecifikus kötôdés között szoros kapcsolat áll fenn. A kötôdés kontextusspecifikus hipotézise szerint a kötôdés vonás jellegú jellemzôi csak bizonyos kontextusban megjelenô kötôdési reprezentációkkal vannak szoros kapcsolatban, másokkal pedig nem. Egy további kérdés, hogy eltérô kapcsolati kontextusokban, különbözô kapcsolati típusok esetén (szülôk, partner, gyerek, barát, expartner, munkatárs) az ego-alter kötődés minôsége különbözô-e. A vonás jellegú kötôdést a Bartholomew és Horowitz (1991) elmélete alapján kidolgozott mérôeszköz, az ECR-R (The Experiences in Close Relationships-Revised, Fraley, Waller és Brennan, 2000; magyar adaptációja Nagy, 2005) Szorongás és Elkerülés skáláival mértük. Az egyén által felsorolt konkrét személyekre vonatkozó ego-alter kötôdést Bartholomew és Horowitz (1991) Relationship Questionnaire (Kapcsolati Kérdőív) kérdőívével vizsgáltuk.

\section{MÓDSZEREK}

\section{Vizsgálati személyek és mintavétel}

Vizsgálatunkban 200 személy vett részt, ebbôl 159 (79,5\%) nô. A vizsgálati minta összegyưjitése egyetemi hallgatók segítségével történt, hólabda módszert és kényelmi mintavételt alkalmazva. Így a mintánk nem volt reprezentatív a teljes magyar populációt illetốen. A vizsgálatban részt vevôk átlagos életkora 27,84 év volt, 18 és 67 év között, ( $S D=$ 10,87). A vizsgálati személyek iskolai végzettsége a következô eloszlást mutatta: általános iskola 6 (3\%), szakmunkás képzô 25 (12,5\%), gimnázium 104 (52\%) és egyetem 
vagy posztgraduális képzés 65 fő (32,5\%). A tesztfelvétel idején 153 (76,5\%) vizsgálati személy rendelkezett romantikus partnerkapcsolattal, és 47 (23,5\%) nem rendelkezett ilyennel. A vizsgálati személyek családi státusza a következô volt: 37 fô (18,5\%) házasságban, 49 (24,5\%) stabil partnerrel, de nem házasságban élt, 5 fố (2,5\%) elvált volt, $11(5,5 \%)$ külön élt házastársától, 97 fő (48,5\%) egyedülálló és korábban még nem házas, és 1 fö $(0,5 \%)$ személy özvegy volt. 117 fố a fơvárosban, (58,5\%), 64 fố (32\%) vidéki városban és 19 fô $(9,5 \%)$ kistelepülésen élt.

\section{A vizsgálat menete}

A vizsgálati személyek online töltötték ki kérdőívünket (Berán és Unoka, 2016). Elôször egy úgynevezett névgenerátor kérdésre válaszoltak. Ebben arra kértük óket, hogy soroljanak fel minden olyan személyt, akivel személyes kapcsolatban voltak az elmúlt hónapban, például együtt töltötték a szabadidejüket, vagy személyes dolgokról beszélgettek. Miután felsorolták ezeket a személyeket egy második névgenerátor kérdéssel arra kértük ôket, hogy soroljanak fel mindenkit, akit érzelmileg közel éreznek magukhoz, függetlenül attól, hogy ez a kapcsolat pozitív, negatív vagy vegyes, valamint függetlenül a találkozás gyakoriságától. Szó szerint ezt kértük:

„Az elôzô oldalon azt kértük Öntôl, hogy sorolja fel minden olyan ismerôsét, akivel legalább havonta egyszer személyesen találkozik. A következőkben a találkozások gyakorisága nem számít: amennyiben elózôleg nem tette, kérjük sorolja fel mindazokat az ismerôseit, akikhez szoros érzelmi kapcsolat füzi, függetlenül attól, hogy ez a kapcsolat pozitív, negatív vagy vegyes érzelmú, és függetlenül a találkozások gyakoriságától. Mindenképpen sorolja fel a következô személyeket, ha korábban nem tette (és még életben vannak): a partnerét, anyját (vagy nevelőanyját), apját (vagy nevelőapját), testvéreit és a legjobb barátait."

Minden egyes személyre vonatkozóan, akit a vizsgálati személyek felsoroltak, számos kapcsolati jellemzôre kérdeztünk rá, ezek közül csak a jelen vizsgálatban szereplô kérdéseket soroljuk itt fel:

- Milyen kapcsolatban van a vizsgálati személy az alterrel (partner, szülô, testvér, gyermek, egyéb rokon, barát, expartner, munkatárs, iskolatárs, szomszéd, egyéb);

- Mióta állnak kapcsolatban egymással: a) kevesebb, mint fél éve, b) fél évtôl egy évig, c) 1 évtôl 3 évig, d) 3 évtôl 10 évig, e) több, mint 10 éve;

- Általában milyen gyakran találkoznak személyesen: a) naponta, b) hetente, c) havonta, d) évente, e) évente párszor, f) ritkábban, mint évente, g) soha;

- Érzelmi közelség a kapcsolatban (egy 0-tól 9 fokig terjedó skálán, ahol a 0 az érzelmi közelség teljes hiányát jelöli, és a 9 nagyon szoros kapcsolatot jelent);

- Az ego-alter kötôdést Bartholomew és Horowitz (1991) Kapcsolati (Relationship Questionnaire) kérdôívével mértük, elkülönítve a biztonságos, a félelemteli-elkerülô, az elárasztott/megszállott és elutasító-elkerüló jellemzóket. A 2. táblázatban látható állításokkal kérdeztünk rá az alterekhez fúződô kapcsolatok kötôdési jellemzőire. Az instrukció a következó volt: Mennyire jellemzik a következó leírások „teszt” nevú ismerósével való kapcsolatát? - ahol a „teszt” szót behelyettesítettük egy 
adott alter nevével. Így a válaszadó összes kapcsolatára rákérdeztünk. A válaszadó egy hétfokú skálán jelölte be, hogy egy adott kötôdési stílus mennyire jellemzi a konkrét kapcsolatot.

2. táblázat.Kötôdési stílus az egyes alterek vonatkozásában (Berán és Unoka, 2016, 149 alapján)

\begin{tabular}{|c|c|c|c|c|}
\hline Kötôdési stílus & \multicolumn{4}{|c|}{7 fokozatú Likert-skála } \\
\hline Biztonságos: & \multicolumn{4}{|c|}{ egyáltalán nem $(0)$ - teljes mértékben (6) } \\
\hline $\begin{array}{l}\text { Teszt nevú ismerôsöm közel áll hozzám, ha } \\
\text { baj van, mindig számíthatok rá. Nem félek } \\
\text { attól, hogy bármikor is cserben hagyna. }\end{array}$ & 012 & 3 & 45 & 6 \\
\hline Félelemteli-elkerülő: & \multicolumn{4}{|c|}{ egyáltalán nem $(0)$ - teljes mértékben $(6)$} \\
\hline $\begin{array}{l}\text { Teszt nevú ismerósömet nehezen engedem } \\
\text { közel magamhoz. Nem érzem, hogy } \\
\text { feltétlenül megbízhatnék benne, vagy } \\
\text { számíthatnék rá. Félek, ha közel engedném, } \\
\text { megbántana. }\end{array}$ & 012 & 3 & 45 & 6 \\
\hline Elárasztott: & \multicolumn{4}{|c|}{ egyáltalán nem $(0)$ - teljes mértékben (6) } \\
\hline $\begin{array}{l}\text { Szeretnék közel kerülni teszt nevú } \\
\text { ismerôsömhöz, de úgy érzem, ô távolságot } \\
\text { tart. Attól tartok, fontosabb ô nekem, mint } \\
\text { én neki. }\end{array}$ & 012 & 3 & 45 & 6 \\
\hline $\begin{array}{l}\text { Elutasító: } \\
\text { Szeretem ha nem vaoyunk érzelmileo túl }\end{array}$ & \multicolumn{4}{|c|}{ egyáltalán nem (0) - teljes mértékben (6) } \\
\hline $\begin{array}{l}\text { kontos, hogy független legyek tốle, és nem } \\
\text { kelljen egymásra támaszkodnunk. }\end{array}$ & 012 & 3 & 45 & 6 \\
\hline
\end{tabular}

Ezenkívül a válaszadó általános, vonás jellegú kötôdési típusát is felmértük, ehhez a Közvetlen Kapcsolatok Élményei kérdôívet töltötték ki a válaszadók (ECR-R, Fraley, Waller és Brennan, 2000; magyar adaptációja: Nagy, 2005).

\section{Etikai megfontolások}

A vizsgálati személyek önként vettek részt a kutatásban, anyagi kompenzáció nélkül. Minden résztvevô aláírta a tájékoztató-beleegyezô nyilatkozatot, melyben beleegyeztek adataik anonim, tudományos célú felhasználásába. A kutatást az Egészségügyi Tudományos Tanács Tudományos és Kutatásetikai Bizottsága (TUKEB) engedélyezte (engedély szám: 38/2013).

\section{Statisztikai elemzések}

Adatgyújtésünkkel a vizsgálati személyek ego-központú kapcsolati hálóját ragadtuk meg. Minden személy k számú altert sorolt fel, és minden k számú alter esetén azonos számú kérdést válaszolt meg. A kérdések vagy az alterre vonatkoztak (alter-kérdések), vagy az alter és az ego közötti kapcsolatra (ego-alter kérdések). Ezen kívül voltak olyan 
kérdések, amelyek csak a vizsgálati személyre vonatkoztak (ego-kérdések). Így két adatbázis hoztunk létre: egy adatbázis n számú adatbevitellel (ego-adatbázis), és egy másikat $n * k n$ számú adatbevitellel (ego-alter adatbázis). A két adatbázist ego- azonosítók segítségével kapcsoltuk össze, így lehetôségünk nyílt mind az alter-, mind pedig az ego-szintú változók elemzésére.

Adataink szükségszerúen nem függetlenek egymástól, ezért a statisztikai elemzésünkben maximum likelyhood alapú hierarchikus lineáris modellezést alkalmaztunk (Lindley és Smith, 1972; Bryk és Raudenbush, 1992; Gibbons, Hedeker, Waternaux, és Davis, 1988; Jennrich és Schluchter, 1986). A Statistical Analysis System (SAS) 14. verziójának GLIMMIX (Generalized Linear Mixed Models) Procedure módszerét használtuk. Ez a módszer figyelembe veszi a megfigyelések közötti korrelációkat, melyek klasztereket alkotnak. Ilyenek például azok az adatok, amelyek egy adott ego-hoz tartoznak. A GLIMMIX modell képes a kategoriális változók, valamint a nem normál eloszlású változók (pl. Poisson and binominális eloszlások) figyelembevételére. Hasonló módon ez a módszer képes az egyes személyekhez tartozó eltéró számú mérések figyelembevételére azáltal, hogy az egyes individuumokat (vagyis az ismételt méréseket, melyek ugyanarra a személyre vonatkoznak) random faktoroknak tekinti. Amennyiben a GLIMMIX modell segítségével szignifikáns kapcsolatot találtunk, kiszámoltuk a legkisebb négyzetek (LS-means) értékét azzal a céllal, hogy az összefüggések irányát meghatározzuk. Azoknál az elemzéseknél, ahol nem használtunk alteradatot, az adatbázist általános, egy sor-egy személy alapon használtuk. A vizsgálati személyek ego-válaszain kívül ebben az adatbázisban további levezetett ego-adatokat hoztunk létre, mint például a felsorolt alterek száma, és más összesített változók, melyeket az ego-alter adatok vagy az alteradatok alapján számoltunk ki.

Elemzésünkben a támogató csoporthoz tartozónak definiáltuk azokat az altereket, akikkel a vizsgálati személy legalább hetente egyszer személyesen találkozott és legalább 8-as fokú érzelmi közelséget jelölt be a 10-fokú skálán (Hill és Dunbar, 2003; Roberts, Wilson, Fedurek, és Dunbar, 2008; Roberts és mtsai, 2009). A szimpátiacsoportot a támogató csoporton kívül esố alterekként határoztuk meg, a névgenerátorban megfogalmazott kritériumok alapján.

\section{EREDMÉNYEK}

\section{Alteradatok}

A vizsgálati személyek összesen 2470 altert soroltak fel, ezekből 1451 (58,74\%) nô volt. Az ego neme és a felsorolt alterek neme között szignifikáns összefüggést találtunk. A nôk 1260 nôi és 747 férfi altert soroltak fel, míg a férfiak 191 nôi és 272 férfi altert ( $\chi^{2}$ $=71,94, p<0,0001)$. Az egyes vizsgálati személyek által felsorolt alterek átlaga 20,04 volt $(S D=12,83$; terjedelem 1-55). A szimpátia csoportban átlagosan 15,71 $(S D=$ 12,35, terjedelem 0-52 fö) alter került, a támogató csoportba pedig 4,33 ( $S D=3,46$, terjedelem 0-17 fô). Az elsố névgenerátorra megadott válaszokban az alterek száma átlagosan 16,41 volt $(S D=11,39$; terjedelem 0-51 fố). Az elsô alterlistát követóen a vizsgálati személyek a második névgenerátorra is válaszoltak, az itt felsorolt alterek 
3. táblázat. Az alterek száma és az ego-alter kötôdési típusok átlag értékei altertípusonként

\begin{tabular}{l|c|c|c|c|c|c|c|c|c}
\hline \multirow{2}{*}{ Altertípusok } & \multirow{2}{*}{$\mathrm{N}$} & \multicolumn{2}{|c|}{ Biztonságos } & \multicolumn{2}{c|}{$\begin{array}{c}\text { Félelemteli/ } \\
\text { elkerüló }\end{array}$} & \multicolumn{2}{c|}{$\begin{array}{c}\text { Elárasztott/ } \\
\text { megszállott }\end{array}$} & \multicolumn{2}{c}{$\begin{array}{c}\text { Elutasító/ } \\
\text { elkerüló }\end{array}$} \\
\cline { 3 - 11 } & & Átlag & Szórás & Átlag & Szórás & Átlag & Szórás & Átlag & Szórás \\
\hline Összes alter & 2470 & 4.09 & 1.83 & 1.02 & 1.54 & 0.87 & 1.39 & 1.7 & 1.86 \\
\hline Partner & 114 & 4.88 & 1.52 & 0.7 & 1.14 & 0.68 & 1.17 & 1.06 & 1.38 \\
\hline Szülón & 293 & 4.89 & 1.49 & 1.22 & 1.75 & 0.67 & 1.15 & 1.7 & 1.77 \\
\hline Testvér & 231 & 4.65 & 1.56 & 0.94 & 1.46 & 1.02 & 1.53 & 1.43 & 1.75 \\
\hline Gyermeke & 40 & 4.97 & 1.56 & 0.52 & 1.47 & 1.55 & 2.33 & 1.35 & 2.09 \\
\hline Egyéb rokona & 265 & 4.4 & 1.58 & 0.94 & 1.48 & 0.8 & 1.25 & 1.74 & 1.88 \\
\hline Barátja & 881 & 4.39 & 1.57 & 0.77 & 1.26 & 0.85 & 1.37 & 1.4 & 1.72 \\
\hline Ex-partnere & 54 & 2.78 & 2.27 & 2.46 & 2.24 & 1.89 & 2.27 & 3.31 & 2.18 \\
\hline Munkatársa & 113 & 2.96 & 1.91 & 1.37 & 1.63 & 0.93 & 1.4 & 2.31 & 2.07 \\
\hline Iskolatársa & 191 & 3.03 & 1.71 & 1.18 & 1.4 & 0.8 & 1.17 & 2.05 & 1.76 \\
\hline Szomszédja & 33 & 2.76 & 1.68 & 1.09 & 1.33 & 0.67 & 1.08 & 2.85 & 1.97 \\
\hline Egyéb & 255 & 2.58 & 1.97 & 1.46 & 1.96 & 0.88 & 1.47 & 2.26 & 2.04 \\
\hline
\end{tabular}

átlaga 3,63 volt ( $S D=3,79$; terjedelem $0-17$ fö). A felsorolt alterek összesített életkori átlaga 32,2, $(S D=16,05$; terjedelem 0-91 fö $)$.

Az alterek altertípusonkénti eloszlása a 3. táblázatban látható. A 225 fôt számláló Egyéb kategóriába vegyes kapcsolat típusok kerültek: rokoni kapcsolatok (nagyszülók, após, anyós, párom testvére, testvérem párja stb.), baráti kapcsolatok (barátnôm), intézményes keretek által meghatározott kapcsolatok (pl., csapattárs, lelki vezetô, pap, tanár, volt foonök) és távolabbi kapcsolatok (pl., ismerôs ismerôse, formálódó barátság). A kapcsolattípusonkénti elemzésbôl ezért ezt a kategóriát kihagytuk.

\section{A mintára jellemzố általános, vonás jellegú kötôdés és az ego-alter jellegú kötôdés}

Az ECR-R Szorongás skálán elért átlag 3,62 ( $S D=1,08)$, az Elkerülés skálán elért átlag $2,53(S D=1,11)$ volt. A Fraley és Shaver (2000) által bevezetett kategorizáció szerint 125 fốt biztonságos kötôdésûnek (szorongás értéke > 4 és elkerülés értéke $>4$ ), 54 fớt elárasztott/megszállottnak (szorongás értéke $<4$ és elkerülés értéke $<4$ ), 9 fốt félelemteli-elkerülônek (a szorongás értéke > 4 és az elkerülés értéke $>4$ ) és 12 fốt elutasító-elkerülônnek (szorongás értéke < 4 és az elkerülés értéke > 4) kategorizáltunk (2. ábra).

A Bartholomew és Horowitz (1991) Kapcsolati kérdőívvel mért ego-alter kötôdési típusok átlag értéke altertípusonként változott. A teljes altermintára kiszámított összátlag a biztonságos kötôdés skálán $(M=4,09, S D=1,83)$ volt a legmagasabb, a három bizonytalan kötôdési skálán pedig viszonylag alacsony: elutasító-elkerülô $(M=1,7, S D$ $=1,86)$, félelemteli-elkerülô $(M=1,02, S D=1,53)$, elárasztott-megszállott $(M=0,87, S D$ =1,39). A biztonságos kötôdés skálán a rokonok, partner és barát altertípusra az összátlag feletti átlagérték, az expartner, munkatárs, iskolatárs, szomszéd és egyéb altertípusokra pedig az átlag alatti átlagérték volt jellemzô. A három bizonytalan kötôdési stílust mérô skála esetén a rokonok, partner és barát altertípusra az összátlag alatti átlag érték jellemzó és a többi alterre pedig az összátlag feletti érték jellemzô (3. táblázat). 
A

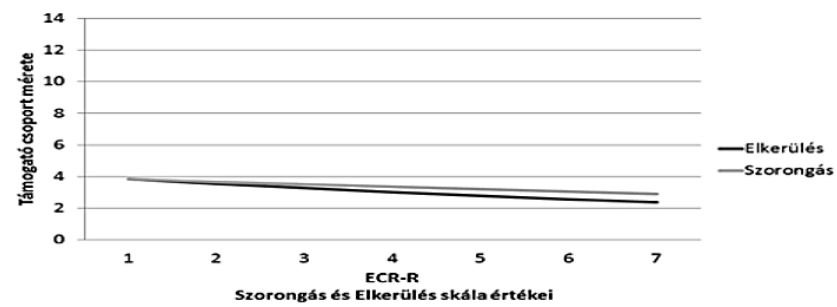

$\mathbf{B}$

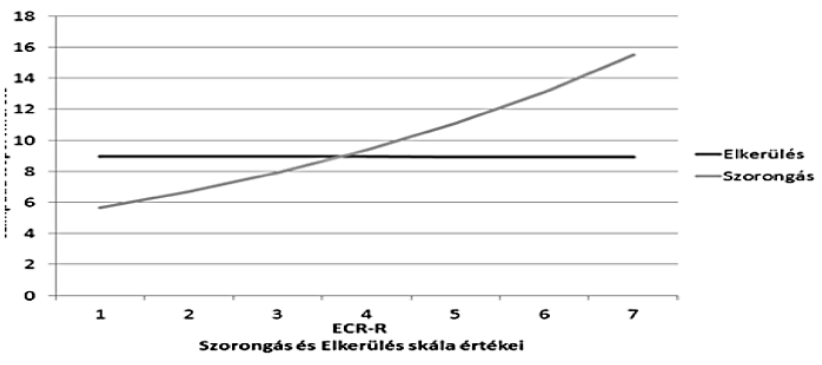

3. ábra. A támogató (A) és a szimpátia- (B) csoport méretének összefüggése az ECR-R Szorongás és Elkerülés dimenzióival

\section{Az ECR-R szorongás és elkerülés skáláinak összefüggése a támogató és szimpátiacsoport méretével}

Az ECR-R skálákon elért pontszám, valamint a támogató és szimpátia csoport mérete közötti összefüggést a GLIMMIX modellel vizsgáltuk. A támogató csoport esetében a modell nem mutatott szignifikáns összefüggést a csoportméret és az Elkerülés skálán elért pontszám $(F(1,198)=2,19, p=0,14)$ valamint a Szorongás skálán elért pontszám között sem $(F(1,198)=0,7, p=0,4)$ (3. ábra).

A szimpátiacsoport esetében az Elkerülés skálán nem találtunk szignifikáns összefüggést a csoportmérettel $(F(1,198)=0,0, p=0,99)$, viszont a Szorongás skála esetében szignifikáns kapcsolatot találtunk $(F(1,198)=6,43, p=0.01)$. Minél magasabb pontszámot ér el valaki a Szorongás skálán, annál nagyobb volt a szimpátiacsoport nagysága (3. ábra).

A vonás jellegú, általános kötôdési stílus és az ego-alter kötôdési stílus összefüggései az összes altermintán

A következô vizsgálati kérdésünk az volt, hogy vajon a vonás jellegú általános kötôdési stílus összefüggésben áll-e az alterekhez való kötôdéssel. Az ego-alter és a vonás jellegú, általános kötôdési stílus összefüggéseinek vizsgálatára szintén GLIMMIX modellt használtunk. Elôször az ECR-R két skálája és az összes alter és ego-alter kötôdési stílusa közötti összefüggést vizsgáltuk. Kérdésünk az volt, hogy a vonás jellegú, általános 
kötôdési stílus szignifikáns kapcsolatban van-e az ego-alter kötôdéssel. Az ECR-R Elkerülés skálája szignifikáns kapcsolatot mutatott az egyének alterek iránti biztonságos $(F(1,2468)=19,97 ; p<0,0001)$, félelemteli-elkerülő $(F(1,2468)=56,02 ; p<0,0001)$, elárasztott $(F(1,2468)=34,67 ; p<0,0001)$, és elutasító-elkerülő $(F(1,2468)=44,17 ; p<$ 0,0001) kötôdési stílusával. Minél magasabb értéket értek el az Elkerülô skálán a vizsgálati személyek, annál kevésbé élték meg biztonságosnak a kötôdésüket az alterekkel szemben, és annál inkább jellemezte alterekhez fưzôdő kapcsolatukat a félelemteli-elkerülố, elárasztott és elutasító-elkerülố kötôdési stílus (4. táblázat).

Az ECR-R kérdôív Szorongás skálája szignifikáns kapcsolatban volt az egyének alterek iránti biztonságos $(F(1,2468)=11.79 ; p<0,001)$, félelemteli-elkerüló $(F(1,2468)$ $=71,72 ; p<0,0001)$, elárasztott $F(1,2468)=125,48 ; p<0,0001)$, és az egyének alterek elutasító-elkerülố kötődésével $(F(1,2468)=34,88 ; p<0,0001)$. Azaz minél alacsonyabb értéket értek el a Szorongás skálán, annál inkább jellemezte óket a biztonságos kötôdési stílus, és minél magasabb értéket értek el a Szorongás skálán, annál inkább jellemezte alterekhez füzôdô kapcsolatukat a félelemteli-elkerülő,elárasztott és elutasító-elkerülô kötôdési stílus (4. táblázat).

\section{A vonás jellegú, általános kötôdési stílus és az ego-alter kötôdési stílus összefüggései az altertípusonként}

A következô kutatási kérdésünk az volt, hogy vajon a vonás jellegú általános kötôdési stílus milyen összefüggésben áll az egyes altertípusokhoz való kötôdéssel. A vonás jellegú, általános kötôdési stílus és az ego-alter kötődési stílus altertípusonkénti összefüggéseinek vizsgálatára szintén GLIMMIX modellt használtunk. Az altertípus kategóriák közül a 'munkatárs', 'iskolatárs', 'szomszéd' kategóriákat egybevontuk a 'többi ismerôs' kategóriába, mert ezek homogén csoportot alkotva eltértek a többi kategóriától. Az 'egyéb' kategóriát kihagytuk az elemzésból, mivel a többi kategória keverékét alkotta. Az ERC-R két skálája és az alter ego-alter kötôdési stílusa közötti összefüggést altertípusonként vizsgáltuk (4. táblázat). Az adatokból kiemelendô, hogy a vonás jellegú ECR-R skálák az ego-alter biztonságos kötôdéssel csak a szülô és a testvér, valamint a többi ismerôs esetén voltak szignifikáns kapcsolatban. Barát esetén az ECR-R Elkerülés skálája mutatott szignifikáns összefüggést. Viszont a partner, a gyerek, az egyéb rokon és az expartner esetén az ECR-R egyik skálája sem állt szignifikáns kapcsolatban az ezen személyekhez fưződô biztonságos kötődési stílussal Az ECR-R partner kapcsolatokra vonatkozó vonásjellegú skálái inkább az ego-alter szülôkhöz és testvérekhez fưzôdô biztonságos kötôdéssel álltak szoros kapcsolatban, és nem a korábbi, illetve a jelenlegi partnerhez fưzôdô biztonságos kötôdéssel. A 4. táblázatban bemutatott eredmények közül kiemelnénk, hogy az ECR-R Szorongás és Elkerülés skálája több altertípusban mutatott összefüggést az ego-alter szintű bizonytalan kötôdési stílusokkal, mint a biztonságos kötôdési stílusokkal. Érdekes módon az ECR-R partner kapcsolatokra vonatkozó vonás jellegú skálái a vizsgálati személyek expartnereihez fúzôdô kapcsolataival állnak legkevésbé kapcsolatban. 
4. táblázat. Az ECR-R ego szintű skálák összefüggése az ego-alter szintû kötôdéssel

\begin{tabular}{|c|c|c|}
\hline & \multicolumn{2}{|c|}{ ECR-R ego szintû́ kötôdés } \\
\hline \multirow[t]{2}{*}{ Skála } & Szorongás & Elkerülés \\
\hline & $\mathrm{F}(\mathrm{DF})$ & $\mathrm{F}(\mathrm{DF})$ \\
\hline \multicolumn{3}{|c|}{ Ego-alter Biztonságos } \\
\hline Összes alter & $11.79(12468) * * *$ & $19.97(12468) * * *$ \\
\hline Partner & $0.09(1112)$ & $0.02\left(\begin{array}{lll}0 & 112\end{array}\right)$ \\
\hline Szülő & $23.84(1291)^{* * *}$ & $10.27(0291)^{* *}$ \\
\hline Testvér & $23.66(1229) * * *$ & $17.74(1229) * * *$ \\
\hline Gyermeke & $1.75(138)$ & $0.01(138)$ \\
\hline Egyéb rokona & $1.45(1263)$ & $2.03(1263)$ \\
\hline Barátja & $0.77(1879)$ & $12.45(1879) * * *$ \\
\hline Ex-partnere & $1.07(152)$ & $0.45(152)$ \\
\hline Többi ismerőse & $5.74(1335)^{*}$ & $7.61(1335)^{* *}$ \\
\hline \multicolumn{3}{|c|}{ Ego-alterFélelemteli-elkerülő } \\
\hline Összes alter & $71.72(12468) * * *$ & $56.02(12468) * * *$ \\
\hline Partner & $17.60(1112) * * *$ & $19.41(1112) * * *$ \\
\hline Szülő & $14.74(1291)^{* * *}$ & $6.29(1291) *$ \\
\hline Testvér & $6.28(1229) *$ & $5.47(1229) *$ \\
\hline Gyermeke & $1.30(138)$ & $1.57(138)$ \\
\hline Egyéb rokona & $0.02(1263)$ & $10.98(1263)^{* *}$ \\
\hline Barátja & $22.62(1879) * * *$ & $29.52(1879) * * *$ \\
\hline Ex-partnere & $1.63(152)$ & $0.74(152)$ \\
\hline Többi ismerôse & $6.65(1335)^{*}$ & $1.34(1335)$ \\
\hline \multicolumn{3}{|c|}{ Ego-alter Elárasztott/megszállott } \\
\hline Összes alter & $125.48(12468) * * *$ & $34.67(12468) * * *$ \\
\hline Partner & $12.89(1112) * * *$ & $9.62(1112)^{* *}$ \\
\hline Szüló & $32.53(1291) * * *$ & $10.82(1291)^{* *}$ \\
\hline Testvér & $12.42(1229) * * *$ & $1.34(1229)$ \\
\hline Gyermeke & $11.26(138)^{* *}$ & $0.76(138)$ \\
\hline Egyéb rokona & $9.44(1263)^{* *}$ & $1.57(1263)$ \\
\hline Barátja & $40.42(1879)^{* * *}$ & $15.19(1879) * * *$ \\
\hline Ex-partnere & $6.39(152) *$ & $0.38(152)$ \\
\hline Többi ismerôse & $8.15(1335)^{*}$ & $1.90(1335)$ \\
\hline \multicolumn{3}{|c|}{ Ego-alter Elutasító-elkerülő } \\
\hline Összes alter & $34.88(12468) * * *$ & $44.17(12468) * * *$ \\
\hline Partner & $2.24(1112)$ & $0.00(1112)$ \\
\hline Szülố & $9.06(1291) * *$ & $5.37(1291)^{*}$ \\
\hline Testvér & $9.21(1229) * *$ & $9.54(1229) * *$ \\
\hline Gyermeke & $1.16(138)$ & $1.71(138)$ \\
\hline Egyéb rokona & $0.00(1263)$ & $7.07(1263)^{* *}$ \\
\hline Barátja & $0.35\left(\begin{array}{ll}1 & 879\end{array}\right)$ & $66.67(1879) * * *$ \\
\hline Ex-partnere & $1.94(152)$ & $1.10(152)$ \\
\hline Többi ismerôse & $5.76(1335)^{*}$ & $0.141(335)$ \\
\hline
\end{tabular}

Jelölés: *: $\mathrm{p}<, 05 * *: \mathrm{p}<, 01 * * *: \mathrm{p}<, 001$ 


\section{Altertípus párok ego-alter kötôdései közötti hasonlóságok}

A monotropikus modell elvetésének céljából a vizsgálati alanyok altertípusonkénti ego-alter kötốdési stílusait párba állítva (pl. szülô-partner, szülő-testvér, partner, testvér stb.) összehasonlítottuk, azt feltételezve, hogy a vizsgálati személyek kötôdése az egyes altertípusokhoz szignifikánsan fog különbözni egymástól. Az altertípus párok ego-alter kötôdései közötti hasonlóságok vizsgálatára szintén GLIMMIX modellt használtunk. Feltételeztük, hogy a szülőkhöz fúzôdố kötôdés különbözni fog a többi altertípushoz fưzôdô kötôdéstôl. Páronként összehasonlítottuk a vizsgálati személyek szülô és partner, szülő és gyermeke, szülő és testvérük, szülő és barát, szülő és a munkatárs altereikhez füzôdô ego-alter kötődésüket mind a négy kötôdési stílus mentén (5. táblázat). A szülókkel megélt biztonságos kötôdés nem különbözött a gyermekkel, a partnerrel és a testvérrel megélt biztonságos kötôdéstôl, viszont szignifikánsan különbözött a baráttal és a munkatárssal megélt biztonságos kötôdéstôl. A félelemteli-elkerüló kötôdés esetén ezzel szemben a szüloohöz való kötôdés szignifikánsan eltért a többi vizsgált altertípushoz való kötôdéstôl, kivéve a munkatársakhoz fưzôdô kötôdést. Az elárasztott/megszállott kötôdési stílus esetén a szülő felé irányuló kötôdés nem különbözött a partner és a munkatárs felé irányulótól, azonban eltért a többi altertípus felé megélttôl. Az elutasító-elkerülô kötôdési stílus esetén a szülôk felé irányuló kötôdés a gyermekre és a testvérre irányulótól nem különbözött, viszont eltért a többi altertípus felé megélt kötôdéstôl.

Megvizsgáltuk azt is, hogy a vizsgálati személyek hasonló, vagy különbözô kötôdési modellt alkalmaznak a jelenlegi és az expartnerükre, valamint a partnerükre és a barátjukra, illetve a testvérükre és a partnerükre. A személy jelenlegi partnerére irányuló kötôdése mind a négy kötôdési stílus mentén különbözött a személy ex-partnerére irányulótól. Az eredményekbôl úgy tûnik, hogy a jelenlegi és a korábbi partnerre eltérô kötôdési modellt alkalmaztak a személyek. A partner és a barát, valamint a testvér és a partner összehasonlításban is találtunk hasonlóságokat is különbségeket (lásd az 5. táblázatot).

5. táblázat.Altertípusokego-alter kötôdései közötti különbségek

\begin{tabular}{l|c|c|c|c|c}
\hline \multirow{2}{*}{ Alter-Alter } & & Biztonságos & $\begin{array}{c}\text { Félelemteli/ } \\
\text { elkerülő }\end{array}$ & $\begin{array}{c}\text { Elárasztott/ } \\
\text { megszállott }\end{array}$ & $\begin{array}{c}\text { Elutasító/ } \\
\text { elkerülő }\end{array}$ \\
\cline { 2 - 6 } & $\mathrm{DF}$ & $\mathrm{F}$ & $\mathrm{F}$ & $\mathrm{F}$ & $\mathrm{F}$ \\
\hline Szülő-Partner & 1405 & 0.01 & $8.62^{* *}$ & 0.00 & $11.59 * * *$ \\
\hline Szülő-Gyermek & 1331 & 0.10 & $5.79^{*}$ & $15.05^{* * *}$ & 1.23 \\
\hline Szülö-Testvér & 1522 & 3.46 & $4.00^{*}$ & $9.02^{* *}$ & 2.74 \\
\hline Szülő-Barát & 11172 & $23.53^{* * *}$ & $23.33^{* * *}$ & $4.22^{*}$ & $6.06^{*}$ \\
\hline Szülö-Munkatárs & 1404 & $117.40^{* * *}$ & 0.62 & 3.67 & $9.06^{* *}$ \\
\hline Partner-Expartner & 1166 & $50.24 * * *$ & $45.65^{* * *}$ & $20.91 * * *$ & $66.25^{* * *}$ \\
\hline Partner-Barát & 1993 & $9.91 * *$ & 0.28 & 1.73 & $4.12^{*}$ \\
\hline Testvér-Partner & 1343 & 1.71 & 2.23 & $4.51 *$ & $3.95^{*}$ \\
\hline
\end{tabular}

Jelölés: *: $\mathrm{p}<, 05 * *: \mathrm{p}<, 01 * * *: \mathrm{p}<, 001$ DF szabadságfok, Glimmix 


\section{DISZKUSSZIÓ}

Vizsgálatunkban a szociális háló jellemzôi és a kötôdés közötti összefüggéseket elemeztük. Elôször az ego-központú szociális háló egyes rétegeinek a mérete és a vonás jellegû szorongás és elkerülố kötôdési dimenziók kapcsolatát vettük górcsố alá, majd a két vonás jellegú kötôdési dimenzió és a kontextusspecifikus ego-alter kötôdés kapcsolatát vizsgáltuk az összes alterre vonatkozóan, valamint altertípusonként. Végül az ego-alter kötôdési típusokat hasonlítottuk össze altertípus páronként, hogy feltérképezzük, vajon hasonló kötôdési modellt alkalmaznak-e a vizsgálati személyek a hálójuk különféle tagjaival szemben, vagy inkább altertípus specifikusan eltérôt.

Eredményeink szerint nincs összefüggés az ECR-R szorongást és az elkerülést mérô skáláján elért pontszám és a támogató csoport mérete között. A szimpátia csoport mérete és az ECR-R szorongás skálája között szignifikáns kapcsolatot találtunk: minél magasabb szintû a kötôdési szorongás, annál nagyobb a szimpátiacsoport mérete, amit fordítva is lehet értelmezni, azaz minél nagyobb a szimpátiacsoport mérete, annál nagyobb a kötôdési szorongás a párkapcsolatban. Az elkerülő kötôdési skálára vonatkozóan nem találtunk összefüggést a szimpátia csoport nagyságával. Ezek az eredmények azt mutatják, hogy a vonás jellegú párkapcsolati kötôdés minôsége összefügg a szimpátiacsoport méretével. Minél szorongóbb kötôdésú valaki, annál több emberrel tart fenn baráti kapcsolatot, bár azokat kevésbé érzi érzelmileg közelállónak. Az ego-központú szociális háló vizsgált két belsô körébe tartozókkal rendszeres a személyes kapcsolattartás (Roberts és mtsai, 2008). Az ebbe a körbe tartozó emberek közül az ECR-R szorongás skáláján magasabb pontot elérô személyeknek több kapcsolatuk van a szimpátiacsoportban. Ez jelentheti azt, hogy ezek a személyek több kapcsolatot akarnak fenntartani azért, hogy folyamatosan legyenek hozzáférhetô emberek, akik beugorhatnak a még fontosabb emberek helyére. Így rendelkezésükre áll egy nagyobb kapcsolati csoport, amelyból meríthetnek. A szimpátiacsoportban, ahol nem annyira magas az érzelmi közelség, mint a támogató csoportban, a magas kötôdési szorongást mutató személy kényelmesebben érezheti magát, és több ilyen barátot vallhat magáénak. Ezt az értelmezést erôsíti meg Hudson és Fraley (2016) vizsgálata, akik azt találták, hogy a magas kötôdési szorongással jellemezhetô embereknek a biztonságosan kötôdôkhöz képest több idôre, fokozottabb érzelmekre és nagyobb fokú önfeltárásra van szükségük ahhoz, hogy egy kapcsolatot „közelinek” éljenek meg. Ugyanakkor, kapcsolati történetek megítélésekor kevésbé tartották azokat intimnek, mint a kevésbé szorongó kötôdésû vizsgálati személyek. Hudson és Fraley (2016) azt a következtetést vonták le, hogy a szorongó kötôdésûek több intimitásra vágynak, ugyanakkor kevésbé észlelik azt, mint a kevésbé szorongó kötôdésûek.

\section{A kötôdési szorongás evolúciós értelmezése}

Ein-Dor és Hirschberger (2016) a kötôdés evolúciós funkcióját emelte ki, melynek szerepét a veszély elkerülésében és a veszélyre adott reakcióban látják. Bowlby (1973) rámutatott, hogy a fenyegetés aktiválja a kötôdési rendszert és annak viselkedéses repertoárját, a közelség, a védelem és a támogatás keresését. Bowlbyval összhangban 
Ein-Dor és Hirschberger szerint a különféle típusú kötôdési stílusok eltérô stratégiákat jelentenek, melyek segítségével az egyén megbirkózik a fenyegetéssel. A kötődési szorongás skálán magas pontszámot mutató személyek veszély esetén sokkal hamarabb reagálnak, mint mások. Ennek oka, hogy folyamatosan monitorozzák környezetüket a különféle potenciális veszélyek felismerésének céljából. A szorongó kötôdôk nem pusztán gyorsabbak másoknál a veszély felismerésében, hanem érzékenyek és pontosak a környezeti és társas jelzések fenyegetés szempontjából történô kiértékelésében, valamint fontos számukra azok másokkal való megosztása is. A szerzók szerint ezzel egyfajta ôrszem funkciót tölthetnek be a csoportban: korán felismerik a veszélyt, és erre másokat is figyelmeztetnek (Ein-Dor és Orgad, 2012). Ennek révén növelik a csoport túlélésének esélyét akut fenyegetés esetén.

\section{A vonás jellegü kötôdési stílus és az alterek iránti kötôdési biztonságosság összefüggései}

Vizsgálatunk másik kérdése az volt, hogy a vonás jellegú kötôdési stílus hogyan függ össze a szociális hálóban található személyek - alterek - iránti kötôdéssel. Eredményeink azt mutatták, hogy minél magasabb értéket értek el a vizsgálati személyek a Közeli Kapcsolatok Élményei kérdôív Elkerülés és Szorongás skáláján, annál kevésbé élték meg biztonságosnak kötôdésüket az alterekkel szemben és annál inkább jellemezte alterekhez fưzôdô kapcsolatukat a félelemteli-elkerülő, az elárasztott-megszállott és az elutasító-elkerülô kötôdési stílus. Mivel a biztonságos kötődési stílusra az alacsony elkerülés és szorongás jellemzô, fenti eredményünket másként fogalmazva azt mondhatjuk, hogy minél biztonságosabb az ego-ra jellemzô kötôdési stílus, annál kevésbé jellemzô az alterekhez füzôdố kapcsolatra a félelemteli-elkerülô, elárasztott és elutasító-elkerüloo kötôdési stílus. Vagyis a személy általános kötôdési biztonsága összefügg az alterekhez füzôdố kötôdési biztonsággal és bizonytalansággal.

A fenti eredmények a monotropikus kötődési modellt látszanak megerôsíteni. Nevezetesen azt, hogy a személy rendelkezik egy általános, vonás jellegú kötôdési stílussal, ami az emberekhez fúződô kapcsolataiban meghatározza a kötôdés minôségét.

A kötôdés kontextusspecifikus hipotézise szerint a kötôdés vonás jellegú jellemzôi csak bizonyos kontextusban megjelenô kötôdési reprezentációkkal vannak szoros kapcsolatban. Eredményeink részben alátámasztják ezt a hipotézist. A vonás jellegú kötôdés és az ego-alter kötődés közötti kapcsolatot altertípusonként vizsgálva azt találtuk, hogy bizonyos altertípusokhoz, de nem mindegyikhez való kötôdés szignifikáns kapcsolatban van a személy vonás jellegú kötôdésével. Figyelemre méltó eredmény, hogy az ego-alter szinten legmagasabb értékeket elérô biztonságos kötôdés skálával a vonás jellegú partnerkapcsolatot jellemzô két ECR-R skála a szülôk és a testvérek felé irányuló kapcsolatokban függ össze a kötôdéssel, azonban a partnerhez vagy az expartnerhez füzôdô kapcsolatokban nem. Úgy tûnik, hogy egy általános párkapcsolati reprezentáció szorosabb kapcsolatban van a szülook és a testvérek felé irányuló biztonságos kötôdési reprezentációkkal, mint a tényleges jelenlegi és volt párok felé irányulókkal. 
A vonás jellegú kötôdés szignifikáns kapcsolatban áll az összes alteren megfigyelhetố ego-alter kötốdésekkel. Azonban az altertípusonként elvégzett elemzés rámutat arra, hogy az általános vonás jellegú kötốdés csak bizonyos ego-alter kontextusokban érvényesül.

\section{Az altertípus párok közötti ego-alter kötődés összehasonlítása}

Azt a kérdést vizsgálva, hogy a vizsgálati alanyok nagyjából hasonló vagy inkább eltérô kötốdési modellt alkalmaznak a legtöbb interperszonális kontextusban, altertípus páronként összehasonlítottuk a Kapcsolati Kérdôívvel ego-alter szinten mért négy kötôdési típust. A vizsgált altertípus párokban több kötôdési stílus esetén találtunk hasonlóságokat és különbségeket. Ez az eredmény megfelel Fraley és munkatársai (2011), valamint Jantek és Vargha (2016) eredményeinek, akik szintén eltéréseket találtak az egyes személyekhez füzốdô kötôdésben. Eredményeink azt az elképzelést erősítik meg, hogy a szociális háló tagjaihoz fúzốdô kapcsolatainkat kapcsolattípusonként, kontextusspecifikusan értékeljük a rendelkezésre álló kötôdési modelljeink segítségével. Ezeknek a differenciált modelleknek a kialakítása, észben tartása, illetve rugalmas, kapcsolattípusonkénti alkalmazása jelentốs kognitív terhet ró az emberre, ami szerepet játszhat a szociális háló belsố körei méretének a korlátozásában.

Ôsszességében azt mondhatjuk, hogy a kötôdési kapcsolat biztonságossága összefüggést mutat a kapcsolati háló méretével. Emellett ugyan globális összefüggést mutat az altereinkhez füzôdô kapcsolatainkkal is, azonban ez az összefüggés altertípusonként eltérô lehet. Másrészt, a szociális hálónk személyeivel kapcsolatban altertípusonként eltérô kötôdési modellt alkalmazhatunk kapcsolataink értékelése során.

\section{IRODALOM}

Ainsworth, M. D. S. (1969). Object relations, dependency, and attachment: a theoretical review of the infant-mother relationship. Child Development, 40(4), 969-1025.

Ainsworth, M. D. S. (1979). Infant-mother attachment. American Psychologist, 34(10), 932-937.

Antonucci, T., Akiyama, H., \& Takahashi, K. (2004). Attachment and close relationships across the life span. Attachment $\mathcal{E}$ Human development, 6(4), 353-370.

Bartholomew, K., \& Horowitz, L. M. (1991). Attachment styles among young adults: A test of a four-category model. Journal of Personality and Social Psychology, 61(2), 226-244.

Berán E., \& Unoka Zs. (2016). Kihez kötốdünk a sok ember közül? In Pléh Cs., Unoka Zs. (szerk.), Hány barátod is van? (pp. 127-156). Budapest: Oriold és Társai.

Bickart, K. C., Hollenbeck, M. C., Barrett, L. F., \& Dickerson, B. C. (2012). Intrinsic amygdalacortical functional connectivity predicts social network size in humans. The Journal of Neuroscience, 32(42), 14729-14741.

Bowlby, J. (1969/1982). Attachment and loss. New York, NY: Basic Books.

Bowlby, J. (1973). Attachment and loss: Vol. 2. Separation: anxiety and anger. New York, NY: Basic Books. 
Brennan, K. A., Clark, C. L., \& Shaver, P. R. (1998). Self-report measurement of adult attachment: An integrative overview. In J. A. Simpson \& W. S. Rholes (Eds), Attachment theory and close relationships (pp. 46-76). New York: Guilford Press.

Bryk, A. S., \& Raudenbush, S. W. (1992). Hierarchical linear models: applications and data analysis methods. London, Thousand Oaks, New Delhi: Sage Publications, Inc.

Collins, N. L., \& Feeney, B. C. (2004). Working models of attachment shape perceptions of social support: evidence from experimental and observational studies. Journal of Personality and Social Psychology, 87, 363-383.

Collins, N. L., \& Read, S. J. (1990). Adult attachment, working models, and relationship quality in dating couples. Journal of Personality and Social Psychology, 58(4), 644-663.

Dunbar, R. (1993). Coevolution of neocortical size, group size and language in humans. Behavioral and Brain Sciences, 16, 681-735.

Dunbar, R. (1996). Grooming, gossip, and the evolution of language. Cambridge, Mass.: Harvard University Press.

Dunbar, R. (2003a). Evolution of the social brain. Science, 302, 1160-1161.

Dunbar, R. (2003b). The social brain: Mind, language, and society in evolutionary perspective. Annual Review of Anthropology, 32, 163-181.

Dunbar, R. Barrett, L., \& Lycett, J. (2005). Evolutionary psychology. Oxford: Oneworld.

Dunbar, R., \& Schultz, S. (2010). Bondedness and sociality. Behaviour, 147, 775-803.

Dunbar, R. I., \& Spoors, M. (1995). Social networks, support cliques, and kinship. Human Nature, 6(3), 273-290.

Ein-Dor, T., \& Orgad, T. (2012). Scared saviors: Evidence that people high in attachment anxiety are more effective in alerting others to threat. European Journal of Social Psychology, 42, $667-671$.

Ein-Dor, T., \& Hirschberger, G. (2016). Rethinking Attachment Theory From a Theory of Relationships to a Theory of Individual and Group Survival. Current Directions in Psychological Science, 25(4), 223-227.

Fiori, K. L., Consedine, N. S., \& Merz, E. M. (2011). Attachment, social network size, and patterns of social exchange in later life. Research on Aging, doi: 0164027511401038.

Fraley, R. C., Waller, N. G., \& Brennan, K. A. (2000). An item response theory analysis of self-report measures of adult attachment. Journal of Personality and Social Psychology, 78(2), 350-367.

Fraley, R. C., \& Shaver, P. R. (2000). Adult romantic attachment: Theoretical developments, emerging controversies, and unanswered questions. Review of General Psychology, 4(2), $132-154$.

Freud, S. (1982). A pszichoanalízis foglalata. In S. Freud: Esszék (pp. 407-474). Budapest: Gondolat.

Gibbons, R. D., Hedeker, D., Waternaux, C., \& Davis, J. M. (1988). Random regression models: A comprehensive approach to the analysis of longitudinal psychiatric data. Psychopharmacological Bulletin, 24, 438-443.

Grossmann, K. E., \& Grossmann, K. (1991). Attachment quality as an organizer of emotional and behavioral responses in a longitudinal perspective. Attachment across the life cycle, 93-114.

Harlow, H. F., Harlow, M. K., Dodsworth, R. O., \& Arling G. L. (1966). Maternal Behavior of Rhesus Monkeys Deprived of Mothering and Peer Associations in Infancy. Proceedings of the American Philosophical Society, 110(1), 58-66.

Hazan, C., \& Shaver, P. (1987). Romantic love conceptualized as an attachment process. Journal of Personality and Social Psychology, 52(3), 511-524. 
Hill, R., \& Dunbar, R. (2003). Social network size in humans. Human Nature, 14, 53-72.

Hudson, N. W., \& Fraley, R. C. (2016). Adult attachment and perceptions of closeness. Personal Relationships. DOI: 10.1111/pere.12166.

Jantek Gy., \& Vargha A. (2016). A felnôtt kötődés korszerú mérési lehetôsége: A közvetlen kapcsolatok élményei-kapcsolati struktúrák (ECR-RS) kötôdési kérdôív magyar adaptációja párkapcsolatban élô felnôtt személyeknél. Magyar Pszichológiai Szemle, 71(3), 447-470.

Jennrich, R. I., \& Schluchter, M. D. (1986). Unbalanced repeated-measures models with structured covariance matrices. Biometrics, 42, 805-820.

Konner, M. J. (1976). Maternal care, infant behavior and development among the ]Kung San. In R. B. Lee \& I. DeVore (Eds), Kalahari hunter-gatherers: studies of the ]Kung San and their neighbors (pp. 218-245). Cambridge, Massachusetts: Harvard University Press.

La Guardia, J. G., Ryan, R. M., Couchman, C. E., \& Deci, E. L. (2000). Within-person variation in security of attachment: a self-determination theory perspective on attachment, need fulfillment, and well-being. Journal of Personality and Social psychology, 79(3), 367-384.

Lindley, D. V., \& Smith, A. F. M. (1972). Bayes Estimates for the Linear Model. Journal of the Royal Statistical Society, Series B (Methodological), 34, 1-41.

Lewis, M. (1987). Social development in infancy and early childhood. In J. Osofsky (Ed.), Handbook of Infancy (2nd Ed.) (pp. 419-493). New York: J. Wiley \& Sons.

Lewis, M. (2005). The child and its family: The social network model. Human Development, $48(1-2), 8-27$.

Marvin, R. S., VanDevender, T. L., Iwanaga, M. I., Levine, S., \& Levine, R. (1977). Infant- caregiver attachment among the Hausa in Nigeria. In H. McGurk (Ed.), Ecological factors in human development. Amsterdam: North-Holland.

Myers, B.J., Jarvis, P. A., \& Creasey, G. L. (1987). Infants' behavior with their mothers and grandmothers. Infant Behavior and Development, 10(3), 245-259.

Nagy L. (2005). A felnőtt kötôdés mérésének egy új lehetôsége: a Közvetlen Kapcsolatok Élményei kérdőív. Pszichológia, 25, 223-245.

Pléh, Cs. (2016). Az én hálózatai a biológiában: Dunbar és barátai. In Pléh Cs., \& Unoka Zs. (szerk.), Hány barátod is van? (pp. 45-57). Budapest: Oriold és Társai.

Ravitz, P., Maunder, R., Hunter, J., Sthankiya, B., \& Lancee, W. (2010). Adult attachment measures: A 25-year review. Journal of Psychosomatic research, 69(4), 419-432.

Roberts, S. G., Dunbar, R. I., Pollet, T. V., \& Kuppens, T. (2009). Exploring variation in active network size: Constraints and ego characteristics. Social Networks, 31, 138-146.

Roberts, S. G., Wilson, R., Fedurek, P., \& Dunbar, R. I. M. (2008). Individual differences and personal social network size and structure. Personality and Individual Differences, 44, 954-964.

Schaffer, H. R., \& Emerson, P. (1964). Patterns of response to physical contact in early human development. Journal of Child Psychology and Psychiatry, 5(1), 1-13.

Schuengel, C., \& van IJzendoorn, M. H. (2001). Attachment in mental health institutions: A critical review of assumptions, clinical implications, and research strategies. Attachment $\mathcal{E} \mathrm{Hu}$ man Development, 3(3), 304-323.

Shultz, S., \& Dunbar, R. I. (2010). Social bonds in birds are associated with brain size and contingent on the correlated evolution of life-history and increased parental investment. Biological Journal of the Linnean Society, 100(1), 111-123.

Seibert, A. C., \& Kerns, K. A. (2009). Attachment figures in middle childhood. International Journal of Behavioral Development, 33(4), 347-355.

Sutcliffe, A., Dunbar, R., Binder, J., \& Arrow, H. (2012). Relationships and the social brain: integrating psychological and evolutionary perspectives. British Journal of Psychology 103, 149-168. 
Trinke, S. J., \& Bartholomew, K. (1997). Hierarchies of attachment relationships in young adulthood. Journal of Social and Personal Relationships, 14(5), 603-625.

van IJzendoorn, M. H., \& Sagi-Schwartz, A. (2008). Cross-cultural patterns of attachment: Universal and contextual dimensions. In J. Cassidy \& P. R. Shaver (Eds), Handbook of attachment: Theory, research, and clinical applications (2nd ed.)(pp. 880-905). New York: Guilford Press.

\section{EGO-CENTERED SOCIAL NETWORK AND ATTACHMENT STYLE}

\section{BERÁN, ESZTER - UNOKA, ZSOLT - SOLTÉSZ, PÉTER - RÁCZ, ANNA - KARDOS, PÉTER - PLÉH, CSABA}

Background: According to Dunbar's social brain hypothesis human intelligence and language skills have developed so that the individual could comprehend and operate the complex system of relationships that developed in large groups about the size of 150 individuals. In our study we examined whether the size of smaller, more intimate groups within this large group are related to the individual's attachment style. At the same time we examined how trait based attachment style is related to attachment towards individual alters within the network, as well as whether we find differences in the ego's attachment to various alter types.

Methods: Our sample included 200 volunteers. The participants filled out our questionaire online. In order to gain information about their social networks, we asked them to list all individuals they have had personal relationship during the past month. We asked them to rate each listed relationship along various dimensions such as how often they meet personally, how close they are emotionally to each other, and how they see their relationship in terms of attachment quality. They also completed the ECR-R inventory.

Results: There was a significant positive relationship between scores on the ECR-R anxiety scale and the size of the sympathy group. Also, the two scales of the ECR-R were significantly related to ego-alter attachment, as well as there was a systematic difference in attachment according to alter types.

Conclusions: The security of attachment relationship is related to network structure and size, and as such, it could potentially be an important predictor of individual differences in network organization. The general trait-based theory of attachment differentiates in attachment among alter types. The differences in attachment towards various alter-types suggest that participants use various internal working models in evaluating different relationships, which casts doubt on the use of a single monothropic model in adult relationships.

Keywords: attachment, social network, support group, sympathy group, ECR-R 